To cite this Article: P. Tani, E. Oksanen-Ylikoski, T. Ylikoski (2016) EDUCATIONAL INSTITUTES AND LARGE-SCALE OUTPLACEMENT PROCESSES - COMBINING EDUCATION WITH SOCIAL RESPONSIBILITY AND OUTREACH, ICERI2016 Proceedings, pp. 4287-4292.

DOI: $10.21125 /$ iceri.2016.0201

URL: https://library.iated.org/view/TANI2016EDU 


\title{
EDUCATIONAL INSTITUTES AND LARGE-SCALE OUTPLACEMENT PROCESSES - COMBINING EDUCATION WITH SOCIAL RESPONSIBILITY AND OUTREACH
}

\author{
Petri Tani ${ }^{1}$, Elina Oksanen-Ylikoski ${ }^{2}$, Teemu Ylikoski ${ }^{1}$ \\ ${ }^{1}$ Laurea University of Applied Sciences (FINLAND) \\ ${ }^{2}$ HUMAK University of Applied Sciences (FINLAND)
}

\begin{abstract}
Outplacement activities are a form of professional care toward dismissed employees. The purpose of outplacement is to offer support for re-employment and making a forced leave easier. Outplacement services often contain recruitment training for writing applications and self-presentation, career counselling, job placement or job search services, and psychological and legal counselling.
\end{abstract}

In outplacement, activities that are common in seeking employment are paid by the downsizing organisation, and not the individual. The activities are often tailored to the organisation's specific needs, location, and industry. Outplacement serves to ease the individual's transition towards new employment, and also, to control the negative impact on an organisation's reputation.

In Finland, nearly 12,000 employees were made redundant in 2015 . Roughly 114,000 employees were under co-determination negotiations potentially leading to termination. Employees' rights against termination of employment can be seen as weaker in the Nordic countries in comparison to Europe in general. To support large-scale redundancies, the Republic of Finland has received support from the European Globalisation Adjustment Fund.

In April 2016, Nokia announced plans for massive reductions in its Finnish workforce, aiming to downsize by 1,300 employees in Finland. Shortly after this, Microsoft announced its plans to terminate its mobile phone design and production operations in Finland, resulting in 1,350 layoffs. Both of these incidents have a direct impact to the larger Helsinki metropolitan area, particularly the City of Espoo.

The City of Espoo took an active role once the reductions were announced and organised a network meeting for different organisations, who might be able to help the transition and re-employment of the affected employees. The City of Espoo is seeking for new approaches in outplacement. One that seems to have a lot of potential is education, as it can help the individual in identifying current capabilities, but also, in training for a new profession.

Laurea University of Applied Sciences partnered with the vocational education provider Omnia to design a joint education program, targeted towards these recently terminated employees in the ICT sector. The program, "Laurea MBA - from digital competences to entrepreneurship", offers new career choices as well as an entrepreneurial path.

For Laurea and Omnia, participating in the outplacement process offers a unique opportunity. First, it ties in with their core tasks of educating individuals and improving their competences. Secondly, it offers a way to achieve social responsibility in an important economic area. Thirdly, the opportunity is also a way to leverage societal impact and outreach, a task which is becoming increasingly important in education.

Traditionally, universities have played a less pronounced role in outplacement processes. However, it appears there are substantial benefits for all parties, and the issue should be investigated more thoroughly, particularly as the importance of self-employment has risen dramatically in the society. Education can be an important means to ensure psychological well-being in the stressful posttermination situation.

Keywords: outplacement, training, entrepreneurship, regional development.

\section{OUTPLACEMENT}

Outplacement may be generally defined "as a consulting and career counselling process that assists both employers and terminated employees in facing transition -organizational change for employers; a new job, career, or lifestyle for employees" [1]. Outplacement is a well-established phenomenon, 
having been introduced in the 1960's in the USA. After that, it has been widely adopted around the world. The service can be provided by the company itself, by external actors, or by both.

Outplacement is a form of professional care that assists departing employees. Lay-offs and downsizing are often major changes in the life of an individual and many need assistance to cope with the change. A downsizing company can choose assist its former or departing employees in transition: help finding new jobs, or in reorientation to the job market. A properly organized and timed outplacement process produces value for both the employer and employee. The purpose of outplacement is to ease the individual's transition towards new employment. However, it is also used to the negative impact of major layoffs on an organisation's reputation.

Over the years, outplacement has become a substantial industry. Different consultancies, training companies and recruitment specialists offer services to potential clients. These can vary from job search training to career counselling and even psychological assistance. These are often tailored to the organisation's specific needs, location, and industry.

Interestingly, outplacement is often viewed as a process of relocating the employee to another position, based on the employee's current skills. However, in today's economic turmoil, it is a valid question to ask, whether this is a viable option. Wouldn't the employee benefit from a larger set of outplacement services, including new training and education? Although educational organizations could provide many of the services and benefits described, they seem rather absent in the outplacement sector. According to research, the role of educational institutes has not been sufficiently studied either [2].

This is an interesting issue, as there is research specifically suggesting that education is an essential and critical element of economic transformations. For instance, Oppong [3] demonstrates a strong relationship between higher education and economic growth both theoretically and empirically. The global financial crisis of 2008 led to high unemployment in many nations across the globe and a reorganisation of the global work market. Some of the massive layoffs around the world are reverberations of this watershed.

\section{CASE FINLAND: NOKIA AND MICROSOFT ANNOUNCE MAJOR LAYOFFS}

The year 2016 has been dramatic in the ICT sector in Finland. In April, Nokia announced plans for cutting some 1,000 jobs. The reductions were primarily related to the Alcatel-Lucent merger and the resulting 900 million euro cost reduction need. Approximately $50 \%$ of the reductions target Nokia's operations in Espoo with the rest splitting roughly in half between two other major sites.

In May, Microsoft announced its plans to terminate its smart phone business in Finland. This results in layoffs for around 1,350 persons. Again, most of the terminated employees work in Espoo. Both companies announced financial support plans and outplacement programs to support the terminated employees.

Nokia announced plans for a new Bridge program to help in the transition. The aim of the Bridge program is to offer a wide range of possibilities for employees from traditional individual reemployment support to making investments in newly founded firms by employees in order to encourage entrepreneurship, retraining people and inspire innovation. When people are at the risk becoming unemployed it is always difficult for the individual and furthermore each employee's situation is unique. The Bridge program takes a proactive approach by investing time, money and expertise to support re-employment. The Program is divided into five different paths: 1 . Find a New Job outside Nokia, 2. Find a job inside Nokia, 3. Start a new business, 4. Learn something new and 5. Create your own path. [4]

For decades, Nokia and later, Microsoft, have represented growth and wealth to the Finnish economy. The impact has reached beyond the companies themselves, into their employees, subcontractors, suppliers, distributors, and the entire Finnish economy. Lucrative, well-paying positions in Nokia were long seen as premium positions in the economy and many if not most of Nokia's employees were wealthy or very well off. The traditional thinking has emphasised higher likelihood of unemployment and job instability in low-income employees [5]. For Nokia and Microsoft, this appears to have been reversed completely.

Nokia's layoffs in 2016 were not the first incidence. In 2012, Nokia announced some 3,700 terminations due to the closing of its mobile phone assembly in Finland. To support this, Nokia launched the first Bridge program. It was launched in spring 2011, and it continued until spring 2014. A 
report on the program deems it very successful, at least as far as the entrepreneurship track is concerned. The program's entrepreneurship track has contributed to starting some 400 companies in Finland set up by around 500 people who became entrepreneurs. About one out of ten employees dismissed from Nokia in Finland in 2011-2013 chose entrepreneurship. [6]

The layoffs of 2016 take largely place in Espoo, the second largest city in Finland. Once the layoffs were announced, the City of Espoo began preparations and organized a network of actors. These organizations aim to find new ways for re-employing the terminated employees. The actor network is a part of the outplacement process.

The network consists of representatives from Nokia and Microsoft, the City, the Finnish government and Ministries, universities, as well as RDI agencies such as the Finnish funding agency for innovation. The City was aiming to ensure rapid re-employment of the dismissed employees, either directly or through education. Entrepreneurship was also seen as a significant employment opportunity.

The Finnish government is seeking EU funding to support the outplacement activities. The Finnish Ministry of Labour filed an application to the European Globalisation Fund in the autumn [7]. To assist in the personal tragedies of those involved, multiple universities and other educational institutions are taking part. From an industry viewpoint, this is also a new opportunity for educational institutions to enter a new service provision territory.

\section{OUTPLACEMENT THROUGH AN MBA PROGRAM - FROM DIGITAL COMPETENCES TO ENTREPRENEURSHIP}

Although it seems often overlooked, education can be a very lucrative option for outplacement, since it can help the individual in identifying current capabilities, but also, in training for a new profession or for entrepreneurship. To achieve this end, Laurea University of Applied Sciences partnered with the City of Espoo and the vocational education provider Omnia to create a new joint program. This educational program is specifically targeted at recently terminated employees in the ICT sector. It is titled Laurea MBA - from digital competences to entrepreneurship", and offers new capabilities for people with competences in the ICT sector, but less in entrepreneurship. The program is intended to support reemployment, possible career changes and the opportunity to update one's skills. As it was developed to address the outplacement needs in 2016, experiences are still limited. This paper documents the progress so far.

Laurea MBA is a new educational program with a specific outplacement flavour. This is seen in the student value promise. For the student, the program offers possibilities to identify and develop individual strengths, assess one's skills and find different realistic career opportunities. It equips the student with service design tools to help in developing one's innovations and gives an understanding of the networks and innovation ecosystems in the business. It familiarises the student with the entrepreneurial process and concrete tools to lead a business idea into a digital product or service. The program's strengths are its close ties with the RDI consortiums and a possibility to take part in matchmaking events between businesses.

The program is constructed of six modules, all designed to help the outplacement process and support a fledgling business idea or innovation (Laurea, 2016). Participants are encouraged to bring to the program any preliminary business concepts, innovations and other ideas that they might have developed. The Laurea MBA program then serves as a vessel to further develop and enhance these ideas, with each program module offering specific insights into the student's idea.

The first module is titled "from digital expert to entrepreneur". It is designed to help identify individual strengths that help in building a new type of future. This module offers tools and methods to assess new career choices and potential entrepreneurship paths.

The second module, "success as an entrepreneur", offers the student with an understanding of the complexity of life in a small business. This is especially important for many terminated employees, whose career paths have often taken place only in very large enterprises. The module equips the participants with tools to control the processes, business models, and eventually, the success of businesses of different sizes.

The third module is titled "insight in service design". It combines vocational, hands-on-skills and the methods of service design in very practical terms. The purpose is to assist the participant in developing new products and services, and creating value through service design. The toolkits of 
service design are applied into the concepts and ideas the participants may have. The key is an understanding of what end user value the innovation might provide for its potential customers.

The fourth module, "digital business", aims to develop the participants' personal digital competences and digital thinking. In the module, the participants learn to employ digital solutions and applications in different business models. The diversity supports participants' capabilities in harnessing digital innovations in their own business logic.

The fifth module is titled "internationalisation and networks". It creates understanding and insights about business opportunities in an international operating field. It gives practical knowledge about business opportunities in other countries and the practicalities of businesses going abroad. The module supports the participant's internationalisation plans through international networks, financing opportunities and support forms.

The sixth and final module consists of an individual development project. The development project is a hands-on-opportunity to enhance, mature and clarify the fledgling business idea that the participants have by this point. The module ties together the themes covered in other modules and combines them in a practical, guided project. The end result supports new career possibilities and entrepreneurial options.

\section{OUTPLACEMENT AND REGIONAL IMPACT}

Educational institutions take part in regional development in various ways. These can vary e.g. from community outreach activities to workplace partnerships to fully developed regional development activities. Feinblatt [8] describes regional development as "a long-term commitment to a public agenda benefiting the greater region in direct collaboration with other regional stakeholders". Internationally, there seem to be vast differences in how educational institutions view themselves, whether as integral parts of the local communities, as completely independent entities, or something in between.

In Finland, Universities of Applied Sciences have been assigned the task of regional development in law. The law requires that education and R\&D are conducted in collaboration with local enterprises, organisations, and public administration. This results in a synergetic effect, where learning and research actions have regional development externalities.

From the point of view of outplacements, the regional dimension offers two interesting aspects. First, taking part in outplacement services is a new way of participating with the local community and providing value. Education provision is at the heart of universities' existence, but there are fewer instances where the need for education is as immediate and direct as in the case of massive layoffs.

Secondly, local educational institutions can leverage their insight into the local economy's needs in an outplacement program. For example, any international major university with highly developed MOOCs could offer education programs for outplacement needs, even in distant Finland. However, only local universities have direct contacts with the area's businesses, what they need, and how the economy is faring. In this sense, regional development can turn into an asset in outplacement activities of an educational institution. Laurea's long history of close collaboration with local businesses and other actors gives it a head start in understanding the needs of the region.

\section{PRACTICAL ISSUES, PROBLEMS AND FINDINGS}

Outplacement is a new field for educational institutions. Although representatives of the Finnish government have been actively participating in the project, some surprising practical hurdles have emerged. One issue relates to the taxation of education benefits.

In Finland, education is a tax-exempt benefit in certain circumstances when an employer offers education to its employees. When a downsizing company offers re-employment training to dismissed or potentially terminated employees, the training is tax-exempt, as long as it does not qualify as degree education. The requirement for tax exemption is that the training must be agreed before the end of employment. The formal termination date of the employment is the determining factor, even if the person is released of all duties before the said date.

However, training that aims to provide the employee with a new profession, is a taxable benefit. The organisation of such training is considered equal to the employee's salary. Should the employer want to compensate the employee's training costs, these are also considered taxable income. Also, potential start-up-capital investments are equally taxable. 
The situation is even more complex: based on the information from Nokia and Microsoft, most of the dismissed employees did not have a degree in higher education.

These restrictions have caused some issues with universities' possibilities in participating in outplacement services. Laurea MBA was designed as a paid additional training to avoid the possibility of tax issues. Should a company want to purchase it as part of its outplacement process, the training is tax-exempt.

Some practical issues relate to the status of employment services. The Finnish government has a significant role in major layoff situations. In Nokia's downsizing episodes, the government has taken an active role and organised dedicated public funding for outplacement activities. Such is the case in the 2016 layoffs as well. However, publicly funded employment services are under the jurisdiction of public procurement. Any participant seeking to offer Nokia's former employees re-training must fulfil the procurement requirements as well. This has been a problem for some participants.

There have been problems with finding a common language with the employees. Although Nokia's terminated employees have a high track record of founding new businesses, the need for a more formal training program does not appear that salient. This may be an issue of timing as well - it is possible that entrepreneurship training becomes more interesting after other potential pathways have been tried out.

\section{CONCLUSIONS}

The process through which people deal with job loss is complex and includes several decisions and crossroads. Outplacement is a way to implement social responsibility for the downsizing businesses, such as Nokia and Microsoft. It can offer practical help in the distress that relates to termination of employment and seeking new opportunities.

Large-scale layoffs such as those described in this paper are significant in the local region of Espoo as well as whole Finland. Because of the impact, many different support forms are needed. These include companies' outplacement programs, public action programs and other initiatives by third parties. In massive layoff situations, the European Union has a substantial role through different support mechanisms.

Laurea University of Applied Sciences joined forces with the City of Espoo and the vocational education provider Omnia to offer a tailored training program to Nokia's and Microsoft's terminated employees. The initiative came from the City, who felt that a closer cooperation with the education institutes would benefit the outplacement field.

The end result is an MBA program that is tailored to building entrepreneurs out of digital specialists. The program leverages the regional insights that the local education institutes have and is closely tied to developing new innovative ideas into fully blown products and services. Some problems have also been found, such as taxation and public procurement issues.

Taking part in new fields outside the traditional scope of education and research has helped the organisations build new competences very quickly. It is also a sign of an agile capability to react to rapid developments in the operating environment. In one sense, being able to provide outplacement services should the region need it, is a prime example of highly developed regional development activity.

As the program is still in launch, our experiences are limited to the first phases. Later research is needed to assess the long term impact of Laurea MBA.

\section{REFERENCES}

[1] Meyer, J.L. \& Shadle, C.C. (1994). The changing outplacement process. Westport, CT: Quorum Books.

[2] Hallqvist, A. \& Hydén, L-C. (2012) Learning in occupational transitions: a study of the process following job loss, 2012, Work: A Journal of Prevention, Assessment and Rehabilitation, (43), 3, 331-343.

[3] Oppong, S. (2013). Should Higher Education Institutions Serve National Economic Needs? Why and Why Not? Education Sciences and Psychology, 25 (3), 90 - 109. 
[4] Nokia (2016). Press release. http://company.nokia.com/en/news/pressreleases/2016/04/06/nokia-launches-headcount-reductions-as-part-of-global-synergy-andtransformation-program.

[5] Goldthorpe, J. H. \& McKnight, A. (2006) The Economic Basis of Social Class. In Morgan, Stephen L, Grusky, David B., Fields, Gary S. (toim.): Mobility and Inequality: Frontiers of Research in Sociology and Economics, 109-133. Stanford: University press.

[6] Kiuru, P., Handelberg, J. and Rannikko, H. (2013) Bridge It Up - the impact of startup services offered for employees - Case Nokia's Bridge Program.

[7] EGR (2016). http://egr.fi/en

[8] Feinblatt, S. (2009), Introduction. In Mohrman, K., Shi, J., Feinblatt, S.E., \& Chow, K. W. (Eds.). Public Universities and Regional Development. Chengdu, Sichuan: Sichuan University Press. 